\title{
Examination of Giardia intestinalis with Direct Microscopy and Direct Fluorescent Antibody in Patients with Diarrhea
}

\author{
Giardia intestinalis'nin İshalli Hastalarda Mikroskopi ve DFA Yöntemiyle \\ Araştırılması
}

\author{
(D) Ahmet Yilmaz ${ }^{1}$, (D) Hakan Uslu ${ }^{2}$ \\ ${ }^{1}$ Atatürk University Vocation School of Health Services, Department of Medical Laboratory Techniques, Erzurum, \\ Turkey \\ ${ }^{2}$ Atatürk University Faculty of Medicine, Department of Medical Microbiology, Erzurum, Turkey
}

Cite this article as: Ylmaz A, Uslu H. Examination of Giardia intestinalis with Direct Microscopy and Direct Fluorescent Antibody in Patients with Diarrhea. Turkiye Parazitol Derg 2020;44(4):187-90.

\begin{abstract}
Objective: In this study, our objective was to compare direct microscopic examination and direct fluorescence antibody (DFA) method for Giardia diagnosis in stool samples and to evaluate the possible risk factors related to Giardia infections.

Methods: Stool samples of 185 patients with diarrhoea collected between June 2019 and July 2019 in Erzurum Yakutiye Research Hospital were included in the study. Microscopic examination of the samples was performed with native-lugol, and they were subsequently scanned by the indirect fluorescent assay microscope using the DFA method at 100-200X magnification. In addition, all patients filled a questionnaire prepared to determine the possible risk factors related to Giardia infection.

Results: The age of the 185 participating patients who belonged to different groups was between 0 and 94 years. Giardia spp. cysts were detected in five stool samples (2.7\%) using direct microscopic examination. Nine samples (4.9\%) were DFA-positive. The incidence of giardiasis was noted to be $7.5 \%$ in children, $3.8 \%$ in adults, $7.3 \%$ in people living in rural areas, $2.9 \%$ in people living in urban areas, $10 \%$ in people having pets and $4.2 \%$ in people who do not have pets.

Conclusion: By taking the DFA method as a reference, the sensitivity and specificity of the microscopic examination were found to be $44.4 \%$ and $99.4 \%$, respectively. The Giardia positivity rate was higher in children, those living in rural areas, those having pets and those using well water as drinking water.
\end{abstract}

Keywords: Giardia spp., diarrhoea, direct fluorescent antibody, direct microscopy, risk factor

\section{ÖZ}

Amaç: Bu çalışmada ishalli dışkı örneklerinde Giardia'nın teşhisinde, direkt mikroskobik bakı yöntemi ile direkt flöresan antikor (DFA) yönteminin karşılaştırılması ve ayrıca Giardia enfeksiyonları için olası risk faktörlerinin araştırılması amaçlanmıştır.

Yöntemler: Haziran-Temmuz 2019 tarihleri arasında Erzurum Yakutiye Araştırma Hastanesi; farklı kliniklerinden 185 hastanın ishalli dışkıları çalışma materyali olarak kullanıldı. Laboratuvara gelen örneklerde; öncelikle native-lügol ile mikroskobik bakı, sonrasında DFA yöntemi kullanılarak IFA mikroskobunda X100-200 büyütmede tarandı. Ayrıca Giardia enfeksiyonunun olası risk faktörleri araştırmak için hastalardan anket formu doldurmaları istendi.

Bulgular: Yaşları 0-94 arasında değişen ve farklı gruplarda yer alan bu hastalara ait 185 fekal örneğin 5'inde (\%2,7) direkt mikroskopi ile Giardia spp.'ye ait kistler görüldü. DFA yöntemiyle örnekleri 9'unda (\%4,9) pozitiflik saptandı. Giardiyozis yaygınlığ çocuklarda \%7,5, yetişkinlerde \%3,8, kırsal bölge de yaşayanlarda \%7,3, şehirde yaşayanlarda \%2,9, evcil hayvan sahiplerinde \%10 ve evcil hayvanı olmayanlarda \%4,2 idi.

Sonuç: DFA yöntemi referans alındığında mikroskobi yönteminin duyarlılığı \%44,4, özgüllüğü ise \%99,4 olarak hesaplandı. Çocuklar, kırsal bölgede yaşayanlar, evcil hayvan besleyenler ve içme suyu olarak kuyu suyu kullananlarda Giardia pozitifliği daha yüksek bulundu.

Anahtar Kelimeler: Giardia spp., ishal, direkt flöresan antikor, direkt mikroskopi, risk faktörü

Received/Geliş Tarihi: 21.03.2020 Accepted/Kabul Tarihi: 08.06.2020

Address for Correspondence/Yazar Adresi: Ahmet YImaz, Atatürk University Vocation School of Health Services, Department of Medical

Laboratory Techniques, Erzurum, Turkey

E-mail/E-Posta: uhakan@hotmail.com ORCID ID: orcid.org/0000-0002-2350-1516

(C) Copyright 2020 Turkish Society for Parasitology - Available online at www.turkiyeparazitolderg.org

(C) Telif hakkı 2020 Türkiye Parazitoloji Derneği - Makale metnine www.turkiyeparazitolderg.org web sayfasından ulașılabilir. 


\section{INTRODUCTION}

Giardia intestinalis (known also as G. lamblia or G. duodenalis) is one of the ten enteric parasites, which are most common among people worldwide (1). Giardia, which was first identified by Antony van Leeuwenhoek in 1681, is a whip-shaped and flagellated parasite and has only trophozoite and cyst forms (2). Contaminated water and food are the main risk factors for Giardia infections. Poor living conditions, being a large family, contaminated environment, usage of raw sewage and low socioeconomic class are other related risk factors $(3,4)$. Giardia infection may also be transmitted directly from infected pets or wild animals (5). Although Giardia infections may be asymptomatic in humans, they may also lead to different clinical courses extending from mild diarrhea to severe malabsorption (6). Conventional microscopic methods are usually used for the diagnosis of Giardia in the laboratories. However, the error margin of the examination of only one stool sample is relatively high if the parasite concentration is low, the quality of the microscopic examination is poor, and the parasite is hidden due to the intermittent shedding and bile pigments (7). Three stool samples should be examined to increase sensitivity (8). For the diagnosis of Giardia, serological methods such as ELISA and direct fluorescence antibody (DFA), which are based on the detection of the parasite antigens in the stool samples, are also used besides the conventional methods $(2,9)$.

In this study, the objective was to compare the direct microscopy using native-lugol and DFA in the diagnosis of Giardia and to evaluate the risk factors of giardiasis with the help of a questionnaire filled by the patients.

\section{METHODS}

The stool samples of 185 patients with diarrhea, who were referred from different clinics of the Erzurum Yakutiye Research Hospital between June 2019 and July 2019, were included in the study. The microscopic examination of the samples admitted to the laboratory was done with native-lugol and then the remaining stool samples were stored at $-20^{\circ} \mathrm{C}$ for the examination with DFA. Meriflour Giardia/Cryptosporidium (made in the USA) kit was used for DFA. The results obtained using positive and negative controls according to the recommendation of the manufacturer and screened under $\mathrm{x} 100-\mathrm{x} 200$ magnification for each well. The slides showing fluorescence were confirmed under higher magnification. The prepared stool specimens, which contained green-apple colored samples with a size between 8-12 $\mu \mathrm{m}$ and the characteristic cyst morphology, were considered positive for the presence of Giardia spp. Necessary approval form for study was taken from patients. In addition, we let the patients fill questionnaires and tried to determine the possible risk factors related to giardiasis.

\section{Statistical Analysis}

The statistical analysis was performed to determine the relationship between the different patient groups (grouped for the age, drinking water source, etc) for the examined parameters. The SPSS software package (v.22.0, SPSS Inc.) was used for all analyses. The p-values $<0.05$ were considered significant according to the results of the Pearson's chi-square test.

\section{RESULTS}

Our study involved 185 patients, who were between the ages of 0-94 years and complained of diarrhea. 97 of the patients were male and 88 of them were female. The age of 53 patients was between 0-14 years and the remaining 132 patients were older than 15 years. In our study, we observed cysts belonging to Giardia spp. in 5 of the 185 stool samples (2.7\%) with direct microscopy. On the other hand, 9 stool samples (4.9\%) were DFA positive. Although four of the five samples diagnosed positive with the direct microscopy were also positive on DFA, the remaining one sample was DFA negative. On the other hand, five samples, which were negative on the microscopic examination, were positive on DFA. The sensitivity, specificity, positive predictive value, and negative predictive value of the direct microscopic examination were determined with the reference to the DFA method (Table 1). The possible risk factors for the Giardia spp. prevalence determined with the data obtained through the used questionnaire were listed in Table 2.

One of the samples containing Giardia spp. under the IFA microscope (DFA method) was shown in Figure 1.

\section{DISCUSSION}

In this study, we determined the prevalence of Giardia spp. in individuals, who had applied to our hospital with the complaint of diarrhea and compared the direct microscopic examination with the DFA for Giardia diagnosis. In addition, we evaluated the data obtained for the possible risk factors related to giardiasis. In Turkey, studies focused on Giardia infections have mostly an epidemiological design. In our study, the prevalence of Giardia

Table 1. Comparison of the results of the DFA method and direct microscopic examination, and sensitivity and specificity level of the direct microscopic examination

\begin{tabular}{|l|l|l|l|}
\hline Tested & DFA (+) n & DFA (-) n & Total \\
\hline Direct microscopy positive & 4 & 1 & 5 \\
\hline Direct microscopy negative & 5 & 175 & 180 \\
\hline Total & 9 & 176 & 185 \\
\hline The evaluation of the direct microscopy & \multicolumn{2}{l|}{} \\
\hline Sensitivity & $44.4 \%$ & $99.4 \%$ & \\
\hline Specificity & $80.0 \%$ & \\
\hline Positive predictive value & $97.0 \%$ & \\
\hline Negative predictive value & & \\
\hline DFA: Direct fluorescence antibody &
\end{tabular}


Table 2. Possible risk factors for the Giardia intestinalis infection

\begin{tabular}{|c|c|c|c|}
\hline Risk factors & n (185) & Positive (\%) & $\mathbf{p}$ \\
\hline \multicolumn{4}{|l|}{ Gender } \\
\hline Male & 97 & $6.2 \%$ & \multirow{2}{*}{0.299} \\
\hline Female & 88 & $3.4 \%$ & \\
\hline \multicolumn{4}{|l|}{ Age groups } \\
\hline $0-14$ years & 53 & $7.5 \%$ & \multirow{2}{*}{0.236} \\
\hline Over 15 & 132 & $3.8 \%$ & \\
\hline \multicolumn{4}{|l|}{ Living area } \\
\hline City & 103 & $2.9 \%$ & \multirow{2}{*}{0.150} \\
\hline Rural & 82 & $7.3 \%$ & \\
\hline \multicolumn{4}{|l|}{ Pets } \\
\hline Yes & 20 & $10 \%$ & \multirow{2}{*}{0.252} \\
\hline No & 165 & $4.2 \%$ & \\
\hline \multicolumn{4}{|c|}{ Drinking-water supply } \\
\hline Bottled water & 15 & $0 \%$ & \multirow{3}{*}{0.324} \\
\hline Tap water & 138 & $4.3 \%$ & \\
\hline Well water & 32 & $9.4 \%$ & \\
\hline
\end{tabular}

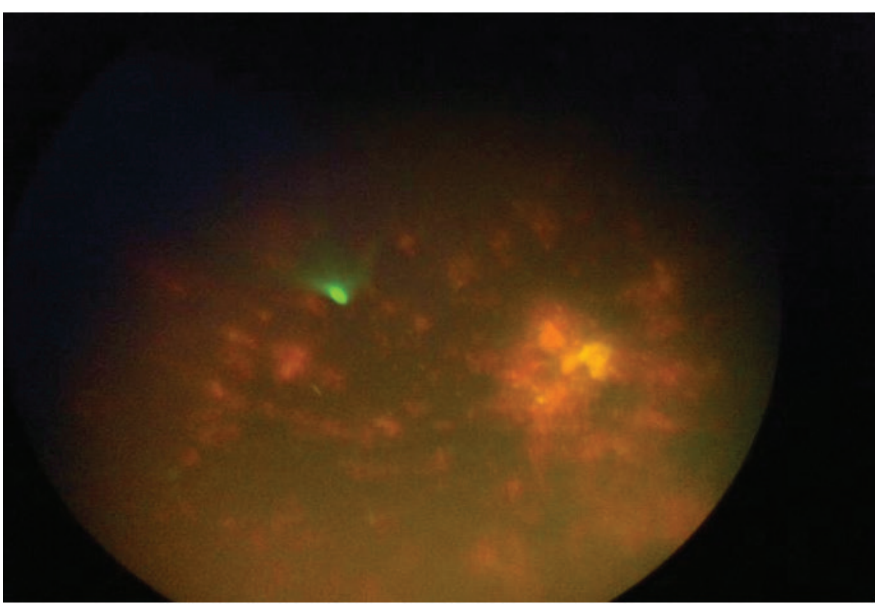

Figure 1. Picture of one of the samples with Giardia spp. detected with DFA (x20)

DFA: Direct fluorescence antibody

determined $2.7 \%$ with direct microscopy and $4.9 \%$ with DFA method. Regarding the studies, which had been conducted with direct microscopy in different regions of our country, the G. intestinalis prevalence was $1.2 \%$ in the study conducted by Arserim et al. (10) in Izmir, 5.7\% in the study conducted by Oncel (11) in Şanlıurfa, $9.4 \%$ in the study conducted by Cengiz et al. (12) in Van and $1.45 \%$ in the study conducted by Baştemir et al. (13) in Manisa.

The DFA method used in the Giardia diagnosis has a very high sensitivity. Garcia and Shimizu (9) reported a $100 \%$ sensitivity level for DFA. In Turkey, there are only a limited number of studies focused on the comparison of the direct microscopic examination and DFA in Giardia's diagnosis. Regarding this limited literature; Kuştimur et al. (14) reported that DFA was useful to determine the protozoa and could be helpful in the routine laboratory practice. Bayramoğlu et al. (15) used DFA in their study for $G$. intestinalis diagnosis with food employees and reported $54.1 \%$ sensitivity and $100 \%$ specificity for the direct microscopy. In the USA, Alles et al. (16) conducted a study, in which DFA was used as a reference, and they reported the sensitivity and specificity rates of the direct microscopy as $66.4 \%$ and $100 \%$ respectively. In Egypt, El-Nahas et al. (17) used DIF (Direct Immunofluorescence Assay) as a reference and reported $76.9 \%$ and $100 \%$ for the sensitivity and specificity of the direct microscopy respectively. In our study, we found that the sensitivity and specificity of the direct microscopy were $44.4 \%$ and $99.4 \%$ respectively for the detection of the Giardia spp. based on DFA as a reference.

It has been reported that Diarrheal disease is the leading cause of death and illness for children under five years of age in developing countries (18). There are several studies focused on the risk groups for giardiasis. Several factors such as gender, childhood-adulthood, living in the rural and urban areas, source of drinking water, and the presence of pets and education level of parents were evaluated in these studies. Julio et al. (19) showed in Portugal that the positivity rate for G. intestinalis was $6.8 \%$ in children aged 0-15. Sagabiel et al. (20) from Germany showed that the positivity rate was $1.5 \%$ among children aged $0-6$ years and Kramar et al. (21) from Russia showed that the same rate was $31.9 \%$ among children aged 0-5 years. In our study, the Giardia prevalence was $8.2 \%$ among children aged $0-14$ years. The same rate was $3.3 \%$ among adults. The prevalence of Giardia is usually higher in children compared to adults. This may be explained by the relatively poor personal hygiene in childhood.

The rate of Giardia is higher in people living in rural areas compared to urban areas. Julio et al. (19) found a Giardia positivity of $5.3 \%$ and $7.4 \%$ in people living in urban and rural areas respectively. Naz et al. (4) showed that the Giardia positivity was $7.3 \%$ and $12.3 \%$ in people living in the urban and rural areas respectively. In our study, the positivity rate was $2.9 \%$ and $7.3 \%$ in people living in the urban and rural areas respectively. Thus, our results were consistent with the results of other studies and in all studies, the positivity rate was higher in people living in rural areas. The close relationship between nature and house environment in rural areas and consequently higher contact with the Giardia species may explain this finding.

Giardia species may cause infections in animals in close contact with humans. In Pakistan, Naz et al. (4) found that the Giardia prevalence was $13.8 \%$ in people with a pet, while the same rate was $9 \%$ in people not having a pet. In Malesia, Choy et al. (22) reported a Giardia prevalence of $12.4 \%$ and $9.6 \%$ for people with and without a pet respectively. In our study, the same rates were $10 \%$ and $4.2 \%$ respectively. These findings showed that giardiasis is considerably higher in people living with pets.

\section{CONCLUSION}

The direct microscopy in the diagnosis of Giardia is a valuable method because of its rapid and easy implementation and the possibility of the detection of other parasites besides Giardia. However, low specificity is the limitation of this method. On the other hand, the high sensitivity of DFA is considered the positive aspect of this method. However, the high cost and requirement of a highly-equipped laboratory environment are the disadvantages of DFA. We conclude that the development of rapid and cost effective immunological diagnostic tests, which may detect simultaneously several parasites, will be very useful. We 
considered children, people in rural areas, people having pets, and people using well water are groups more under risk of giardiasis.

\section{ACKNOWLEDGEMENTS}

The authors would like to thank Dr. Önder Akkaş MD for the collection of Giardia samples.

\section{* Ethics}

Ethics Committee Approval: Our study was approved by the Ethics Committee for Clinical and Laboratory Research in the Medical Faculty of Atatürk University (approval date: 30.05.2019, no: 55).

Informed Consent: Patient consent form and questionnaire were prepared.

Peer-review: Internally peer-reviewed.

\section{* Authorship Contributions}

Concept: A.Y., H.U., Design: A.Y., Data Collection or Processing: A.Y., H.U., Analysis or Interpretation: A.Y., H.U., Literature Search: A.Y., H.U., Writing: A.Y., H.U.

Financial Disclosure: No support was received for this study. Conflict of Interest: The authors declare that they have no conflict of interest to disclose.

\section{REFERENCES}

1. Sulaiman IM, Cama V. The biology of Giardia parasites. Foodborne parasites: Springer; 2006.p.15-32.

2. Gillespie S, Pearson RD. Principles and practice of clinical parasitology. New York: John Wiley \& Sons; 2003.p.229.

3. Savioli L, Smith H, Thompson A. Giardia and Cryptosporidium join the 'Neglected Diseases Initiative'. Trends Parasitol 2006; 22: 203-8.

4. Naz A, Nawaz Z, Rasool MH, Zahoor MA. Cross-sectional epidemiological investigations of Giardia lamblia in children in Pakistan. Sao Paulo Med J 2018; 136: 449-53.

5. Heyworth MF. Giardia duodenalis genetic assemblages and hosts. Parasite 2016; 23: 13.

6. Murray PR, Rosenthal KS, Pfaller MA. Medical Microbiolgy. London: Elsevier Health Sciences; 2013.

7. Gharavi M, Fallahi S, Qara-gozlou B, editors. Evaluation of Giardia detection by routine parasitical assays and antigen detection techniques. In: 5th national Iranian congress of parasitology Tehran, Iran; 2005.p.346-
8. Garcia LS. Diagnostic medical parasitology. Washington, DC. 2001.p.1315.

9. Garcia LS, Shimizu RY. Evaluation of nine immunoassay kits (enzyme immunoassay and direct fluorescence) for detection of Giardia lamblia and Cryptosporidium parvum in human fecal specimens. J Clin Microbiol 1997; 35: 1526-9.

10. Arserim SK, Limoncu ME, Gunduz T, Balcioglu IC. Investigation of Intestinal Parasites in Living Nursing Home. Turkiye Parazitol Derg 2019; 43: 74-7.

11. Oncel K. Distribution of Intestinal Parasites Detected in Sanliurfa Mehmet Akif Inan Education and Research Hospital Between October 2015 and October 2016. Turkiye Parazitol Derg 2018; 42: 20-7.

12. Cengiz ZT, Beyhan YE, Çiçek M, Yılmaz H. Bir üniversite hastanesi parazitoloji laboratuvarında belirlenen intestinal ve hepatik parazitler. Dicle Med J 2015; 42: 350-4.

13. Baştemir S, Öncel K, Yereli K, Kilimcioğlu AA, Balcıoğlu C, Girginkardeşler N. Frequency of Intestinal Parasites Detected in the Laboratory of Medical Parasitology in Celal Bayar University Hafsa Sultan Hospital Between 2011 and 2015. Turk Mikrobiyol Cem Derg 2016; 46: 76-81.

14. Kuştimur S, Al FD, Tuncer C, Çamurdan AD, Dalgıç B, Alagözlü H, et al. Gastrointestinal yakınmaları olan hastalarda bazı protozoonların farklı tanı yöntemleriyle araştırılması. Turkiye Klinikleri J Med Sci 2009; 29: 1260-6.

15. Bayramoğlu Ö, Pekmezci D, Başarı F. Adana İli Gıda Çalışanlarında Giardia ve Cryptosporidium Prevalanslarının Farklı Yöntemler ile Araștırılması. Turkiye Parazitol Derg 2013; 37: 4-8.

16. Alles AJ, Waldron MA, Sierra LS, Mattia AR. Prospective comparison of direct immunofluorescence and conventional staining methods for detection of Giardia and Cryptosporidium spp. in human fecal specimens. J Clin Microbiol 1995; 33: 1632-4.

17. El-Nahas HA, Salem DA, El-Henawy AA, El-Nimr HI, Abdel-Ghaffar HA, El-Meadawy AM. Giardia diagnostic methods in human fecal samples: a comparative study. Cytometry B Clin Cytom 2013; 84: 44-9.

18. Einarsson E, Ma'ayeh S, Svard SG. An up-date on Giardia and giardiasis. Curr Opin Microbiol 2016; 34: 47-52.

19. Julio C, Vilares A, Oleastro M, Ferreira I, Gomes S, Monteiro L, et al. Prevalence and risk factors for Giardia duodenalis infection among children: a case study in Portugal. Parasit Vectors 2012; 5: 22.

20. Sagebiel D, Weitzel T, Stark K, Leitmeyer K. Giardiasis in kindergartens: prevalence study in Berlin, Germany, 2006. Parasitol Res 2009; 105: 6817.

21. Kramar' LV, Reznikov EV, Kramar' OG. Prevalence if giardiasis in Volgograd city population. Med Parazitol (Mosk) 2003; 38-9.

22. Choy SH, Al-Mekhlafi HM, Mahdy MA, Nasr NN, Sulaiman M, Lim YA, et al. Prevalence and associated risk factors of Giardia infection among indigenous communities in rural Malaysia. Sci Rep 2014; 4: 6909. 